\title{
PEMBENTUKAN PERATURAN DAERAH DALAM PENYELENGGARAAN OTONOMI DAERAH
}

\author{
Marten Bunga \\ Mahasiswa Program Doktor Ilmu Hukum Pascasarajana UMI Makassar \\ email: marten.bunga@ymail.com
}

\begin{abstract}
Regulations in the area of regional autonomy is as a policy instrument in the regional administration of the widest. The formation of local regulations in accordance with the public interest its implementation should be based on the principles of local autonomy and substance of local regulations must not conflict with the public interest and the law is higher.

Keywords : Local Regulation, Autonomy.
\end{abstract}

\begin{abstract}
Abstrak
Peraturan di bidang otonomi daerah adalah sebagai instrumen kebijakan dalam pemerintahan daerah yang seluas-luasnya. Pembentukan peraturan daerah sesuai dengan kepentingan publik pelaksanaannya harus didasarkan pada prinsip-prinsip otonomi daerah dan substansi peraturan daerah tidak boleh bertentangan dengan kepentingan publik dan hukum lebih tinggi.

Kata kunci: Peraturan Daerah; Otonomi Daerah;
\end{abstract}

\section{A. PENDAHULUAN}

Kebebasan daerah dalam membentuk peraturan daerah merupakan hak, karena merupakan instrumen kebijakan hukum pemerintahan daerah dalam menampung aspirasi masyarakat, mengatasi berbagai masalah yang timbul baik yang sudah ada, atau kemungkinan akan ada di masa yang akan datang dalam rangka otonomi daerah. Peraturan daerah merupakan bagian dari peraturan perundang-undangan di Indonesia.Namun demikian, dalam realitasnya setelah dilakukan evaluasi oleh Kementerian Hukum dan HAM terdapat sebanyak 4.000 (empat ribu) Peraturan Daerah di seluruh Indonesia dibatalkan, karena tidak memenuhi kualifikasi untuk diterapkan.

Pembentukan Perda yang pada akhirnya sebagian besar dari Perda tersebut dibatalkan, sebagai akibat adanya berbagai masalah yang teridentifikasi sebagai berikut :

1. Kemampuan para perancang peraturan daerah (legal drafter) yang tidak cukup, baik dari segi teknik hukum maupun dari substansi hukum dari peraturan daerah yang akan dibuat;

2. Peraturan daerah yang dibuat belum mampu menterjemahkan secara utuh suatu kebijakan pemerintahan ke dalam bahasa normatif;

Vol. 19 No. 2, November 2017 
3. Peraturan daerah yang dibuat, secara substansif belum dapat berfungsi sebagai instrumen mengatur, mengurus, dan perlindungan;

4. Umumnya pembuatan peraturan daerah lebih diarahkan pada upaya meningkatkan pendapatan asli daerah melalui pemungutan (pajak dan retribusi daerah), serta masih sangat kurang yang diarahkan pada pengaturan/penataan;

5. Akibat dari orientasi peraturan daerah hanya untuk pemungutan, menyebabkan daerah (melalui peraturan daerah) tidak memperhatikan karakteristik daerah, dan karakteristik masyarakat di daerah yang bersangkutan;

6. Pembuatan peraturan daerah tidak demokratis,sehingga akan menyebabkan tidak adanya ruang keterbukaan, partisipasi masyarakat dan sulitnya penciptaan akuntabilitas dalam penyelenggaraan urusan pemerintahan, terutama yang berkaitan dengan pelayanan umum; dan

7. Adanya kecenderungan daerah untuk mengadopsi peraturan daerahdari daerah yang lain, karena kurangnya pemahaman tentang hakikat peraturan daerah sebagai terjemahan kebijakan daerah yang harus disesuaikan dengan kekhususan daerah.

Dengan realitas yang demikian itu, maka dalam pembentukan Perda permasalahan tersebut tidak boleh dibiarkan berlanjut terus,tanpa ada usaha untuk mengantisipasinya. Karena itu, solusi yang dapat dijadikan instrumen pemecahan masalah, adalah melalui Instrumen hukum atau kaidah hukum yang mengatur mengenai pembuatan Perda.

Kewenangan pembentukan Perda, secara transparan dan limitatiftelah diatur dalam Undang Undang Nomor 23 Tahun 2014 tentang Pemerintahan Daerah. Di dalam Penjelasan Umum UU No. 23 Tahun 2014, dengan tegas dinyatakan bahwa tujuan pemberian otonomi luas kepada daerah diarahkan untuk mempercepat terwujudnya kesejahteraan masyarakat, melaluipeningkatan pelayanan, pemberdayaan dan peran serta masyarakat.

Selanjutnya dengan mengacu pada tujuan pemberian otonomi kepada daerah, dan dengan memperhatikan kedudukan Perda dalam rangka penyelenggaraan pemerintahan daerah, ditemukan adanya beberapa fenomena yang dapat diidentifikasi sebagai persoalan hukum. Adapun konkretisasi dari persoalan-persoalan hukum penyelenggaraan pemerintahan daerah dimaksud, antara lain:

1. Adanya kecenderungan penyelenggaraan pemerintahan daerah yang tidak efektif dan efisien;

2. Peraturan daerah cenderung memberikan kesempatan yang besar kepada pemerintah dibandingkan dengan kesempatan yang diberikan kepada masyarakat;

3. Peraturan daerah tidak menetapkan fasilitas yang diharapkan mampu mendukung terwujudnya kesejahteraan masyarakat;

4. Peraturan daerah tidak menetapkan standar operasional prosedur penyelenggaraan urusan umum pemerintahan, sehingga dalam pelaksanaan pemerintahan sering menimbulkan penyalahgunaan wewenang;

5. Peraturan Daerah dan/atau Peraturan Kepala Daerah tidak menetapkan secara tegas pembagian tugas, dan wewenang dalam rangka penyelenggaraan urusan pemerintahan;

6. Peraturan daerah tidak menetapkan sarana keterbukaan yang memungkinkan Vol. 19 No. 2, November 2017 
masyarakat untuk lebih aktif dalam melakukan pengawasan; dan

7. Peraturan daerah tidak menetapkan instrumen perlindungan, bahkan belum ada ketentuan yang secara khusus mengatur mekanisme penegakan peraturan daerah, dan organ yang diberi wewenang untuk menegakkan peraturan daerah.

Dalam kenyataannya pemberlakuan otonomi daerah tidak dibarengi dengan kesiapan masyarakat dan perangkat daerah dalam menghadapinya, yang mana terbukti dengan pembentukan Perda yang berjumlah relatif banyak, dan pemberlakuannya kadang tidak efektif dan efisien.

Kendatipun demikian,secara pragmatis peraturan daerah dianggap sebagai peraturan yang paling dekat untuk mengagregasi nilai-nilai masyarakat di daerah. Peluang ini terbuka, karena peraturan daerah dapat diberi muatan dengan nilai-nilai yang diidentifikasi sebagai kondisi khusus daerah, sehingga tidak tertutup kemungkinan suatu peraturan daerah telah sesuai dengan kepentingan masyarakat, namun bertentangan dengan peraturan yang lebih tinggi dari peraturan daerah.

Bertitik tolak dari uraian di atas, menunjukan adanya fakta empirik demikian banyaknya peraturan daerah yang dibatalkan, sebagai akibat dalam pembentukannya yang kurang memperhatikan syarat-syarat yang telah ditentukan. Karena itu, diperlukan adanya pengkajian yang mendalam berkenaan dengan pembentukan peraturan daerah dalam sistem penyelenggaraan otonomi daerah.

\section{B. ANALISIS DAN PEMBAHASAN}

Peraturan daerah adalah peruturan perundang-undangan yang dibentuk oleh DPRD dan Kepala Daerah yang berfungsi sebagai:

1. Instrumen kebijakan untuk melaksanakan otonomi daerah dan tugas pembantuan sebagaimana amanat UUD NRI Tahun 1945 dan peraturan perundang-undangan di bidang pemerintahan daerah.

2. Menampung keberagaman daerah, penyaluran aspirasi masyarakat di daerah. Namun pengaturannya tetap dalam kerangka negara kesatuan Republik Indonesia yang berlandaskan Pancasila dan UUD NRI Tahun 1945.

3. Alat pembangunan dalam meningkatkan kesejahteraan daerah.

4. Peraturan pelaksanaan dari peraturan perundang-undangan yang lebih tinggi. Oleh karena itu agar tidak tumpang tindih antara Perda dengan aturan yang lebih tinggi sehingga perlu memperhatikan aspek-aspek sebagai berikut:

a. Aspek kewenangan yang secara tegas dipersyaratkan dalam ketentuan Pasal 1 ayat (1) Undang-undang Nomor 12 Tahun 2011 tentang Pembentukan Peraturan Perundang-undangan ;

b. Aspek keterbukaan adalah setiap pembentukan Perda diperlukan adanya keterbukaan bagi masyarakat, baik itu akademisi maupun praktisi untuk berpartisipasi dalam proses perencanaan, persiapan dan penyusunan untuk memberikan masukan atau pertimbangan secara lisan atau tertulis sesuai dengan ketentuan peraturan perundang-undangan; 
c. Aspek pengawasan, yaitu dalam pembentukan Perda harus silakukan pengawasan, baik berupa pengawasan preventif terhadap rancangan Perda maupun pengawasan represif terhadap Perda.

Salah satu fungsi otonomi daerah adalah dalam rangka penguatan integritas nasional. Dengan otonomi, maka akan tercipta mekanisme di mana daerah dapat mewujudkan sejumlah fungsi politik terhadap pemerintahan nasional, hubungan kekuasaan menjadi lebih adil, sehingga daerah akan memiliki kepercayaan. Dengan otonomi, maka proses demokrasi dapat dijalankan dan akan ditopang terwujudnya demokrasi dalam pemerintahan dan pada akhirnya pembangunan daerah akan tercapai.

Otonomi daerah dapat berjalan dengan baik apabila memperhatikan fungsi-fungsi yang ada dalam otonomi daerah seperti fungsi pendidikan politik, mengembalikan hakhak politik masyarakat di daerah, membangun demokrasi dari bawah dan mempercepat pembangunan di daerah.

\section{Otonomi Daerah dan Pendidikan Politik}

Banyak masyarakat tidak menyadari bahwa salah satu fungsi utama dari otonomi daerah adalah fungsi pendidikan politik. Dengan dibentuknya pemerintahan di daerah, maka sejumlah lembaga di daerah demokrasi akan terbentuk pula, terutama partaipartai politik, kelompok kepentingan, kelompok penekan, media massa lokal dan lembaga perwakilan rakyat. Lembaga-lembaga tersebut, akan memainkan peranan yang strategis dalam rangka pendidikan politik warga masyarakat, menanamkan nilainilai dan norma-norma yang berkaitan dengan kehidupan berbangsa dan bernegara. Nilai-nilai tersebut mencakup nilai yangbersifat kognitif, efektif atau evaluatif.

Pengalaman menunjukkan bahwa pertemuan yang diselenggarakan oleh partai politik, wakil rakyat atau dialog antara Walikota/Bupati dengan masyarakat merupakan proses yang sangat bermanfaat bagi ketiga dimensi pendidikan politik. Dengan demikian otonomi daerah mempunyai dimensi integratif yang sangat bermakna bagi sebuah negara. Belum lagi yang menyangkut keberadaan partai politik, dan kelompokkelompok kepentingan yang ada di daerah yang ikut membentuk watak politik serta menyiapkan individu untuk direkrut agar terlibat dalam proses politik.

Pada zaman orde baru warga masyarakat di daerah sudah terbiasa dengan institusi demokrasi yang sudah lama terbentuk sejak masa pemerintahan zaman orde lama. Hanya saja kecenderungan pendidikan politik yang mengarah pada penanaman nilainilai yang diyakini oleh rezim yang berkuasa, maka tidak jarang proses pendidikan politik menjadi suatu hal yang kontra produktif terhadap pemerintah itu sendiri, yaitu menciptakan warga negara yang kritis dan kemudian menolak kehadiran penguasa. Proses pendidikan politik lebih menekankan pada indoktrinasi politik, bukan pendidikan politik yang alami, apalagi perilaku politik yang diperlihatkan menyimpang dari nilai-nilai politik yang ditanamkan. 


\section{Pemberian Kembali Hak-hak Politik Masyarakat}

Otonomi daerah adalah juga pemberian kembali hak-hak politik masyarakat di daerah yang telah mengalami proses marginalisasi dan bahkan alienasi, terutama terjadi pada masa pemerintahan orde baru yang sangat sentralistik.Salah satu dimensi yang sangat menonjol yang berkaitan dengan hak-hak politik warga masyarakat, adalah rekrutmen politik lokal. Pada masa Orde Baru misalnya, rekrutmen politik lokal sangat bersifat tertutup, karena ditentukan oleh mekanisme yang sama sekali tidak transparan, serta tidak memberikan peluang kepada warga masyarakat untuk menentukan sendiri siapa yang akan memimpin mereka, baik dalam bidang politik ataupun dalam bidang pemerintahan. Masyarakat di daerah sama sekali tidak punya peluang untuk ikut terlibat dalam proses tersebut. Kalaupun ada, keterlibatannya hanyalah sebatas meramaikan pada tingkat nominasi calon, tetapi yang menentukan adalah lembaga-lembaga tertentu. Sedangkan DPRD pada dasarnya hanya mempunyai peranan menetapkan secara formal saja. Biasanya tidak hanya sebatas pada jabatan politik dalam pemerintahan, bahkan untuk menjadi ketua partai ditentukan dengan mekanisme yang sama. Akibatnya masyarakat mengalami proses alienasi, yang kemudian membawa implikasi yang sangat jauh, yaitu terbentuknya sentimen kedaerahan yang berlebihan sebagaimana yang dialami sekarang ini dalam pemerintahan daerah.

Hal lain yang berkaitan dengan pengembalian hak dari warga masyarakat daerah, adalah pembuatan kebijaksanaan publik di daerah, dimana Pemerintah Daerah memiliki hak untuk menentukan sendiri apa yang menjadi wewenang dan tanggung jawabnya.

\section{Membangun Demokrasi dari Bawah}

Desentralisasi membawa pengaruh terhadap terbangunnya demokrasi dari bawah, karena dengan adanya pemerintahan daerah yang mandiri yang ditopang dengan praktek-praktek demokrasi yang benar dan baik, sehingga akan menjadi pilar bagi pengembangan demokrasi dalam pemerintahan nasional.

Demokrasi yang dikembangkan dari bawah akan menciptakan mekanisme pola hubungan yang seimbang antara pemerintah dengan daerah, karena masyarakat di daerah akan memiliki peluang rekrutmen ataupun perencanaan pembangunan di daerah dan akan mampu memberikan kontrol terhadap pemerintahan nasional. Dengan demikian demokrasi tidak hanya terbatas menjadi domainnya pusat. Masyarakat di daerah berhak dan harus mampu menyatakan dengan tegasdan jelas bahwa tidak semua yang ditentukan dari pusat itu benar, dan sesuai dengan kehendak masayarakat di daerah.

\section{Otonomi Daerah dan Percepatan Pembangunan}

Daerah menentukan apa yang menjadi skala prioritas serta bagaimana merencanakan dan menjadikannya sebagai kebijakan pembangunan di daerah. Karena itu, Bupati/Walikota bersama DPRD harus memiliki kemampuan untuk menentukan 
prioritas. Otonomi tidak identik dengan meningkatkan Pendapatan Anggaran Daerah (PAD) melalui pungutan. Namun menjadi tugas utama pemerintah daerah untuk menyediakan fasilitasi terhadap proses interaksi dengan berbagai pihak. Pemerintah daerah harus mampu mempermudah izin kegiatan usaha, memotong jaringan birokrasi yang berbelit-belit dan menyediakan insentif-insentif tertentu bagi kalangan masyarakat yang mau menanamkan modalnya.

Disamping itu, masyarakat di daerah harus menciptakan iklim berusaha yang kondusif guna menarik kalangan investor menanamkan modalnya di daerah. Kalangan politisi harus menjamin terciptanya stabilitas politik dan pemerintahan, sehingga kalangan dunia usaha merasa yakin modal yang akan mereka tanamkan tidak akan siasia.Demikian pula dengan kalangan pekerja harus menunjukkan sikap dan tuntutan yang masuk akal dan melakukan negosiasi dengan jaminan proses produksi akan tetap berjalan.

Otonomi daerah yang dicanangkan diharapkan akan mempercepat pertumbuhan dan pembangunan daerah, di samping menciptakan keseimbangan pembangunan daerah. Kebijksanaan pembangunan yang sentralistik membawa dampak terjadinya ketimpangan antar daerah. Otonomi daerah memiliki sejumlah kewenangan, terutama kewenangan wajib yang merupakan modal dasaryang sangat penting untuk pembangunan daerah, sehingga diharapkan dari pemerintah daerah itu, adalah :

a. Menyediakan fasilitas guna mendukung segala bentuk kegiatan di daerah terutama dalam bidang perekonomian. Segala bentuk perizinan hendaklah dipermudah, bukan sebaliknya, yaitu dengan menciptakan bentuk birokrasi yang akan menyulitkan kalangan pengusaha dan investor untuk menanamkan modalnya di daerah tersebut. Pemerintah daerah juga dapat menawarkan fasilitas perpajakan yang merangsang penanaman modal, bukan sebaliknyakegiatan ekonomi sematamata sebagai subjek pemungutan untuk memperoleh peningkatan PAD.

b. Pemerintah daerah harus kreatif. Pembangunan daerah berkaitan pula dengan inisiatif dari para penyelenggara pemerintahan. Kreatifitas tersebut menyangkut bagaimana mengalokasikan dana secara tepat, adil dan proporsional. Selain itu, kreatifitas juga menyangkut kapasitas untuk menciptakan keunggulan komparatif bagi daerahnya, sehingga kalangan pemilik modal akan beramai-ramai menanamkan modal di daerah tersebut. Kreatifitas juga menyangkut kemampuan untuk menarik Dana Alokasi khusus dari pemerintah, sehingga banyak dana dari pusat kedaerahnya. Untuk itu, pemerintah daerah harus mampu menyiapkan program-program sosial, ekonomi yang menarik, sehingga pemerintah tidak ragu memberikan dukungannya.

c. Politik lokal yang stabil. Masyarakat dan pemerintah di daerah harus menciptakan suasana politik lokal yang kondusif bagi dunia usaha dan pembangunan ekonomi. Selain itu, pejabat eksikutif harus bekerja dengan suasana yang tenang sehingga merangsang kreatifitasnya. 
d. Pemerintah Daerah harus menjamin kesinambungan berusaha. Ada kencenderungan yang menghawatirkan berbagai pihak bahwa pemerintah daerah seringkali merusak tatanan yang sudah ada. Apa yang sudah disepakati sebelumnya, baik melalui "Kontrak" dalam negeri atau pihak asing, seringkali diancam untuk ditinjau kembali oleh pemerintah daerah yang baru dengan alasan otonomi daerah. Kalangan pengusaha asing dan domestik seringkali merasa terganggu dengan sikap kalangan politisi dan birokrasi lokal. Karena itu, pemerintah daerah harus meningkatkan kapasitas aparatnya.

e. Pemerintah daerah harus komunikatif dengan Lembaga Swadaya Masyarakat (LSM), terutama dalam bidang perburuhan dan lingkungan hidup. Pemerintah daerah sekarang dituntut untuk memahami dengan intensif aspirasi yang berkembang dikalangan pekerja, baik yang menyangkut upah minimum dan jaminan hak-hak pekerja pada umumnya. Dengan demikian pemerintah daerah hendaknya menjadi jembatan antara kepentingan dunia usaha dengan aspirasi kalangan pekerja. Pemerintah daerah juga harus lebih sensitif dengan masalah atau isu lingkungan hidup serta gender.

Kelima elemen tersebut di atas, merupakan prakondisi bagi terselenggaranya pembangunan daerah. Dengan kebijaksanaan otonomi yang luas, maka peluang bagi daerah menjadi sangat luas pula, dan semuanya sangat bergantung pada daerah itu sendiri. Desentralisasi adalah sebuah mekanisme penyelenggaraan pemerintahan yang menyangkut pola hubungan antara pemerintahan pusat dengan pemerintahan daerah. Di dalam mekanisme ini, pemerintahan pusat melimpahkan kewenangan kepada pemerintahan daerah untuk diselenggarakan guna meningkatkan kemaslahatan hidup masyarakat.

Kalangan ilmuan pemerintahan dan politik pada umumnya mengidentifikasi sejumlah alasan bahwa desentralisasi perlu dilaksanakan, adalah : (1) dalam rangka peningkatan efesiensi dan efektifitas penyelenggaraan pemerintahan; (2) sebagai wahana pendidikan politik masyarakat di daerah; (3) dalam rangka memelihara keutuhan negara kesatuan atau integritas nasional; (4) untuk mewujudkan demokrasi dalam penyelenggaraan pemerintahan yang dimulai dari daerah; (5) guna memberikan peluang bagi masyarakat untuk membentuk karir dalam bidang politik dan pemerintahan; (6) sebagai wahana yang diperlukan untuk memberikan peluang bagi masyarakat untuk berpartisipasi dalam proses perencanaan dan pelaksanaan pemerintahan; (7) sebagai sarana yang diperlukan untuk mempercepat pembangunan di daerah; dan (8) guna mewujudkan pemerintahan yang bersih dan berwibawa.

Adanya desentralisasi politik adalah pelimpahan kewenangan dari pemerintah pusat yang menimbulkan hak mengurus kepentingan rumah tangga sendiri bagi badanbadan politik di daerah-daerah yang dipilih oleh rakyat dalam daerah-daerah tertentu. Desentralisasi fungsional adalah pemberian hak dan kewenangan pada golongangolongan untuk mengurus kepentingan dalam masyarakat, baik terkait maupun tidak pada suatu daerah tertentu, seperti mengurus pada kepentingan irigasi 
bagi golongan tani dalam suatu daerah tertentu. Desentralisasi kebudayaan memberikan hak pada golongan-golongan kecil dalam masyarakat menyelenggarakan kebudayaannya sendiri (mengatur pendidikan dan agama dan lain-lain).

\section{Peraturan Daerah Sebagai Produk Legislatif}

Di dalam Pasal 7 UU No.12 Tahun 2011, terdapat pola divergensi produk hukum nasional yang didesain dalam bentuk jenjang peraturan perundang-undangan yakni:

a. Produk hukum yang mengatur regulasi yang resmi disebutkan dalam sistem hukum berdasarkan UUD NRI Tahun 1945;

b. Tipelogi produk hukum apa saja yang secara hirarkis memiliki kedudukan lebih tinggi dan produk hukum mana saja yang secara hirarkis mempunyai kedudukan hukum yang lebih rendah di antara produk peraturan perundang-undangan;

c. Tipologi produk hukum apa saja yang secara hirarkis berada dibawah undangundang dan/atau Perpu.

d. Tipologi produk hukum apa saja yang diakui keberlakuaanya selain yang telah disebutkan dalam Pasal 7 ayat (1) UU Nomor 12 Tahun 2011.

Menurut sistem hukum Indonesia, peraturan perundang-undangan disusun dalam suatu tingkatan yang disebut hirarki peraturan perundang-undangan. Tata urutan menunjukkan tingkatan dari pada masing-masing bentuk yang lebih tinggi dari pada bentuk-bentuk yang disebut belakangan. Disamping itu, tata urutan mengandung konsekuensi bentuk hukum peraturan yang lebih rendah tidak boleh mengandung materi yang bertentangan dengan materi yang dimuat dalam suatu peraturan yang bentuknya lebih tinggi.

Adanya sistem hirarki, bertujuan untuk memperjelas kedudukan hukum dan kekuatan mengikat secara hukum oleh tiap-tiap produk peraturan perundang- undangan dalam sistem tata hukum nasional. Peraturan Daerah tidak dapat disebut sebagai produk regulatif atau executive acts seperti halnya peraturan pemerintah ataupun peraturan presiden. Peraturan daerah seperti halnya undang-undang, kedua- duanya merupakan produk legislatif.

Kewenangan pembentukan peraturan daerah menempatkan DPRD sebagai organ utama pembentuk peraturan daerah. Produk legislatif adalah peraturan yang ditetapkan oleh atau dengan melibatkan peran lembaga perwakilan rakyat baik sebagai legislator maupun sebagai co-legislator. Produk regulatif adalah produk pengaturan oleh lembaga eksekutif yang menjalankan peraturan yang ditetapkan oleh lembaga legislatif dengan mendapatkan delegasi kewenangan untuk mengatur lebih lanjut materi muatan produk legislatif yang dimaksud ke dalam peraturan pelaksanaan yang lebih rendah tingkatannya.

Kegiatan legislasi dilakukan oleh lembaga perwakilan rakyat, sedangkan regulasi merupakan pengaturan oleh lembaga eksekutif yang menjalankan produk 
legislasi dan mendapatkan delegasi kewenangan untuk mengatur (regulasi) dari produk legislasi yang bersangkutan.

Proses pembentukan, baik peraturan daerah maupun undang-undang, mengikuti ketentuan dalam UU No. 12 Tahun 2011. Hanya saja undang-undang memiliki keberlakuan yuridis secara nasional, sedangkan peraturan daerah terbatas pada wilayah hukum pemerintahan daerah yang bersangkutan. Namun demikian mekanisme rekrutmen wakil rakyat di Pusat (DPR) tidak berbeda dengan proses pengisian jabatan keanggotaan para wakil rakyat di daerah (anggota DPRD), yakni melalui mekanisme pemilihan umum (Pemilu) yang dipilih secara langsung oleh rakyat.

Kedudukan DPRD pada tingkat Provinsi maupun Kabupaten/Kota pada hakikatnya berperan selaku lembaga perwakilan rakyat yang menjalankan kekuasaan legislatif di tingkat daerah. Kedudukan DPRD sebagai pemegang otoritas legislatorlokal, makin mendapat pengakuan secara tegas dengan adanya Undangundang Nomor 42 tahun 2014, tentang MPR, DPR, DPD dan DPRD (UU MD3). Secara substantif undang-undang ini, mengatur secara ekslusif peran dan fungsi dari tiap-tiap lembaga perwakilan rakyat. Karena itu, setiap produk peraturan daerah yang merupakan produk legislatif, tidak boleh diubah apalagi dibatalkan sepihak oleh pemerintah daerah tanpa adanya persetujuan dari DPRD. Tugas pemerintah daerah adalah melaksanakan peraturan daerah sebagaimana mestinya dalam rangka menjalankan roda pembangunan daerah.

\section{Peraturan Daerah Sebagai Produk Hukum}

Tata urutan peraturan perundang-undangan telah mengandung beberapa prinsip yang penting untuk diperhatikan, karena suatu peraturan yang baik adalah mengandung prinsip-prinsip antara lain:

a. Peraturan perundang-undangan yanglebih tinggi kedudukannya dapat dijadikan landasan atau dasar hukum bagi peraturan perundang-undangan yang lebih rendah atau berada dibawahnya;

b. Peraturan perundang-undangan yang lebih rendah tidak boleh menyimpang atau bertentangan dengan peraturan perundang-undangan yang lebih tinggi tingkatannya;

c. Isi atau muatan peraturan perundang-undangan yang lebih rendah tidak boleh menyimpang atau bertentangan dengan peraturan perundang-undanganyang lebih tinggi tingkatannya;

d. Suatu peraturan perundang-undangan hanya dapat dicabut atau diganti atau diubah dengan peraturan perundang-undangan yang lebih tinggi atau paling tidak dengan yang sederajat; 
e. Peraturan perundang-undangan yang sejenis apabila menganut meteri yang sama, maka peraturan yang terbaru harus diberlakukan, walaupun tidak dengan secara tegas dinyatakan bahwa peraturan yang lama itu dicabut.

Secara teoretik istilah perundang-undangan (legislation) mempunyai dua arti, yaitu: pertama; perundang-undangan merupakan proses pembentukan atau proses membentuk peraturan-peraturan negara, baik ditingkat pusat maupun di tingkat daerah; dan kedua; perundang-undangan adalah segala peraturan negara yang merupakan hasil pembentukan peraturan-peraturan baik tingkat Pusat maupun di tingkat Daerah.

Peraturan perundang-undangandapat juga diartikan, yaitu : a) setiap keputusan tertulis yang dikeluarkan pejabat atau lingkungan jabatan yang berwewenang yang berbasis aturan tingkah laku yang bersifat atau mengikat umum; b) merupakan aturanaturan tingkah laku yang berisi ketentuan-ketentuan mengenai hak, kewajiban, fungsi, status atau suatu tatanan; c) merupakan peraturan yang mempunyai ciri-ciri umum abstrak atau abstrak umum, artinya tidak mengatur atau tidak ditujukan pada objek, peristiwa atau gejala konkrit tertentu. Dengan demikian peraturan perundangundangan pada prinsipnya haruslah : (1) bersifat umum dan komprehensif yang merupakan kebalikan dari sifat-sifat khusus dan terbatas; (2) bersifat universal, yaitu diciptakan untuk menghadapi peristiwa-peristiwa yang akan datang yang belum jelas bentuk konkritnya. Karena itu, tidak dapat dirumuskan untuk menghadapi peristiwaperistiwa tertentu saja; (3) memiliki kekuatan untuk mengoreksi dan memperbaiki dirinya sendiri.

Secara implikasi peraturan perundang-undangan juga dapat dimaknai sebagai proses pembentukan produk hukum yang melibatkan sejumlah lembaga Negara, sesuai kewenangannya masing-masing baik di tingkat pusat maupun di daerah untuk merumuskan dan mengesahkannya.

Di dalam Pasal 1 UU No.12 Tahun 2011 ditentukan bahwa :

(1) Pembentukan Peraturan Perundang-undangan adalah proses pembuatan Peraturan Perundang-undangan yang mencakup tahapan perencanaan, persiapan, tehnik penyusunan, perumusan, pembahasan, pengesahan atau penetapan dan pengundangan.

(2) Peraturan Perundang-undangan adalah Peraturan tertulis yang memuat norma hukum yang mengikat secara umum dan dibentuk atau ditetapkan oleh lembaga negara atau pejabat yang berwenang melalui prosedur yang ditetapkan dalam peraturan perundang-undangan.

Tata urutan perundang-undangan dapat dikaitkan dengan teori perundangundangan bahwa kaidah ukum yang merupakan suatu susunan berjenjang dan setiap kaidah hukum yang lebih rendah bersumber dari kaidah hukum yang lebih tinggi. Menurut Hans Kalsen bahwa hukum itu tidak lain adalah kehendak penguasa. Ada 
tiga lapisan norma hukum yaitu norma dasar, aturan-aturan dasar dan peraturan perundang-undangan.

Diantara lapisan-lapisan tersebut, dapat saja ada lapisan lain yang merupakan bagian-bagiannya yang disebutnya dengan stupa antara (zwischenstufe). Sudah tentu tiap lapisan stupa tersebut, berisi norma-norma hukum yang bersifat umum (generelle normen), mengingat suatu norma berlaku umum. Norma fundamental negara yang merupakan norma tertinggi dalam suatu negara ini, adalah norma yang tidak dibentuk oleh suatu norma dahulu oleh masyarakat dalam suatu negara dan merupakan suatu norma yang menjadi tempat bergantungnya norma-norma hukum di bawahnya. Norma yang tertinggi ini tidak dibentuk oleh norma yang lebih tinggi lagi, karena jika demikian maka ia bukan lagi merupakan norma yang tertinggi.

Tata urutan peraturan perundang-undangan dalam UU No.12 Tahun 2011 ditentukan dalam Pasal 7, yaitu :

(1) Jenis dan hierarki Peraturan Perundang-undangan terdiri atas:

a. UUD NRI Tahun 1945;

b. Ketetapan Majelis Permusyawaratan Rakyat;

c. UU/Peraturan Pemerintah Pengganti Undang-Undang;

d. Peraturan Pemerintah;

e. Peraturan Presiden;

f. Peraturan Daerah Provinsi; dan

g. Peraturan Daerah Kabupaten/Kota.

(2) Kekuatan hukum Peraturan Perundang-undangan sesuai dengan hierarki sebagaimana dimaksud pada ayat (1).

Selanjutnya dalam Pasal 8 UU No. 12 Tahun 2011, menentukan :

(1) Jenis Peraturan Perundang-undangan selain sebagaimana dimaksud dalam Pasal 7 ayat (1) mencakup peraturan yang ditetapkan oleh MPR, DPR, DPRD, MA, MK, BPK, KY,Bank Indonesia, Menteri, badan, lembaga. Atau komisi yang setingkat yang dibentuk dengan undang-undang atau pemerintah atas perintah undangundang, DPRD provinsi,gubernur, DPRD Kabupaten/Kota, Bupati/walikota, kepala desa atau yang setingkat.

(2) Peraturan Perundang-undangan sebagaimana dimaksud pada ayat (1) diakui keberadaannya dan mempunyai kekuatan hukum mengikat sepanjang diperintahkan oleh Peraturan Perundang-undangan yang lebih tinggi atau dibentuk berdasarkan kewenangan.

Peraturan daerah merupakan salah satu bentuk dari pada produk hukum daerah yang bersifat pengaturan (regeling) dan penetapan (beschikking). Produk hukum daerah yang bersifat beschikking, yakni Peraturan Kepala Daerah baik pada tingkat 
Provinsi, dan Kabupaten/Kota. Jika merujuk pada ketentuan dalam Peraturan Menteri Dalam Negeri Nomor 53 Tahun 2011 tentang Pembentukan Produk Hukum Daerah, maka ada tiga jenis produk hukum daerah yang dikualifikasikan sebagai bentuk pengaturan (regeling) tersebut, yaitu: (a) Peraturan Daerah (Provinsi atau Kabupaten/Kota) atau sebutan dalam bentuk nama lainnya; (b) Peraturan Kepala Daerah (Gubernur atau Bupati/Walikota); (c).Peraturan bersama Kepala Daerah/ PB.KDH yang dibuat secara bersama antara Gubernur atau bupai/Walikota.

Keberadaan UU Nomor 12 Tahun 2011 menyelesaikan kontradiksi antara bentuk produk hukum yang masuk dalam wilayah produk regeling dan penetapan yang bersifat administrastif (beschikking). Nomenklatur atau istilah keputusan lazim dipakai baik untuk norma hukum yang bersifat regeling maupun beschikking. Misalnya keputusan Presiden yang bersifat regelling dan ada pula yang bersifat beschikking.

Gubernur, Bupati/Walikota dan lembaga-lembaga negara seperti KPU terbiasa menggunakan sebutan Keputusan, baik untuk produk-produk pengaturan (regelling) maupun untuk penetapan-penetapan yang bersifat adminitrasi (beschikking). Namun setelah diundangkannya UU Nomor 12 Tahun 2011, penggunaan kedua istilah peraturan dan keputusan itu dibedakan dengan tegas. Peraturan merupakan produk pengaturan (regelling) sedangkan keputusan merupakan produk penetapan yang bersifat adminitratif (beschikking).

Berdasarkan uraian di atas, konstruksi sistem hukum Indonesia mengenal adanya tata urutan atau hirarki peraturan perundang-undangan yang distratifikasikan secara bertingkat atau berjejang. Tata urutan yang dimaksud menunjukkan kedudukan sekaligus kekuatan keberlakuan (daya ikat secara hukum) dari tiap-tiap produk hukum yang bersangkutan, dimana produk yang lebih rendah tingkatannyua, materi pembentukannya tidak boleh kontradiktif dengan produk hukum yang statusnya lebih tinggi.

Sistem hirarki peraturan perundang-undangan merupakan pijakan normatif yang harus diperhatikan oleh setiap pengambil keputusan (decision making), maupun setiap penegak hukum. Memperhatikan ketentuan normatif mengenai model tingkatan peraturan perundang-undangan di atas, maka tentunya setiap hirarki produk perundangundangan mempunyai implikasi hukum yang berbeda, tetapi saling berkaitan satu sama lain. Implikasi hukum berkenaan dengan perihal kewenangan yuridis terhadap pengujian produk hukum berupa Peraturan Daerah.

Lembaga pembuat peraturan dimungkinkan menguji produk hukumnya sendiri, dan apabila kewenangannya dilekatkan pada legislative, maka pengujiannya disebut legislative review. Apabila kewenangannya pada eksekutif atau pemerintah, maka pengujian disebut executive review. Akan tetapi jika kontrol normatif terhadap peraturan yang dikeluarkan oleh eksikutif, dilakukan oleh lembaga kekuasaan kehakiman, maka pengujian disebut judicial review. Pengujuian ini, dimaksudkan 
untuk mencegah agar kegiatan pemerintah dalam menjalankan pemerintahan tidak terjebak pada praktik otoriter.

Dalam praktek menurut Jimly Asshiddiqie dikenal adanya tiga macam norma hukum yang dapat diuji (norm control mechanism). Ketiganya sama-sama merupakan bentuk norma hukum sebagai hasil dari proses pengambilan keputusan, yaitu (a) keputusan normatif yang berisi dan bersifat pengaturan (regeling), (b) keputusan normatif yang berisi dan bersifat penetapan administratif (beschikking), (c) keputusan normatif yang berisi dan bersifat penghakiman (judgement) yang biasa disebut dengan vonnis.

Ketiga norma hukum tersebut, sama-sama dapat diuji kebenarannya melalui mekanisme peradilan (justisial) atau mekaniksme non-justicial. Jika pengujian itu dilakukan oleh lembaga peradilan, maka proses pengujiannya itu disebut sebagai judicial review atau pengujian oleh lembaga judicial atau pengadilan.

Toetsingrecht atau hak untuk menguji itu, diberikan kepada lembaga parlemen sebagai lagislator, maka proses pengujian demikian itu lebih tepat disebut sebagai lagislative review. Demikian pula jika hak menguji (toetsingrecht) itu diberikan kepada pemerintah, maka pengujian seperti itu disebut sebagai excutive review.

Secara umum, norma hukum itu dapat berupa keputusan-keputusan hukum (a) sebagai hasil kegiatan penetapan yang bersifat administrasi (beschikking), (b) sebagai hasil kegiatan penghakiman atau mengadili berupa vonnis oleh hakim; (c) sebagai hasil kegiatan pengaturan (regelling) baik yang berbentuk legislasi berupa legislative acts ataupun yang berbentuk regulasi berupa executive acts.

Berdasarkan uraian di atas, maka pada perinsipnya kontrol normatif atau sistem pengujian terhadap norma hukum dapat dilakukan sendiri oleh lembaga pembuatannya (kontrol internal), ataupun dilakukan oleh lembaga lain (kontrol eksternal) tergantung pada subjek yang membuat dan objek yang diuji dari sebuah produk hukum tersebut. Jika produk hukum tersebut dibuat oleh pejabat atau badan administrasi negara (produk regulatif) yang bercirikan: (a) merupakan peraturan yang abstrak (abstract norm), (b) harus bersifat mengatur (regelling), (c) harus mengikat secara umum, maka sistem pengujiannya melalui mekanisme executive review atau administrative review. Khusus mengenai keputusan pejabat atau badan administrasi negara yang berisi dan bersifat penetapan administratif yang konkrit, final dan individual, maka proses pengujiannya masuk dalam ranah salah satu organ pelaksana kekuasaan kehakiman.

Jadi semua bentuk penyimpangan atau kekeliruan perbuatan administrasi negara berupa pembuatan produk hukum yang berisi dan bersifat pengaturan (regelling) dapat diawasi pelaksanaannya melalui executive review. Sedangkan terhadap produk hukum berupa keputusan normatif yang berisi dan bersifat penetapan administrasi (beschikking), dapat diawasi pelaksanaanya melalui kontrol lembaga yudikatif.Di samping itu, jika pengujian dilakukan oleh lembaga pengadilan, maka 
proses pengujiannya (judicial review) ditujukan khusus terhadap peraturan (regelling) yang telah mendapat pengesahan. Proses judicial review terhadap setiap peraturan daerah maupun peraturan perundang-undangan yang hirarkinya dibawah undangundang terhadap undang-undang, harus didasarkan pada tolak ukur atau standar normatif tertentu.

Peraturan daerah sangat penting dalam penyelenggaraan otonomi, karena peraturan daerah dapat melancarkan pembangunan daerah dari segala bidang. Karena

itu, peraturan daerah sangat dibutuhkan dalam penyelenggaran otonomi daerah, karena dapat dijadikan sarana untuk mengatur daerahnya sendiri sesuai dengan tujuan yang ingin dicapai.

\section{PENUTUP}

Hakikat peraturan daerah dalam penyelenggaraan otonomi daerah adalah sebagai instrumen kebijakan dalam penyelenggaraan pemerintahan daerah yang seluas- luasnya. Pembentukan peraturan daerah yang sesuai dengan kepentingan masyarakat pelaksanaannya harus berdasar pada prinsip-prinsip otonomi daerah dan materi muatan peraturan daerah tidak boleh bertentangan dengan kepentingan umum dan perundangundangan yang lebih tinggi.

\section{DAFTAR PUSTAKA}

Amiroeddin Syarif, 1997. Perundang-undangan (Dasar, Jenis dan Teknik Membuatnya). Bandung, Rineka Cipta.

Jayadi Nas Kamaluddin, 2002. Otonomi Daerah dan Pemilihan Kepala Daerah. Makassar, Hasanuddin University Press.

Padmo Wahjono, 1991.Menyelisik Proses Terbentuknya Peraturan Perundang-undangan. Jakarta, Majalah Forum Keadilan.

Siswanto Sunarto, H., 2008. Hukum Pemerintahan Daerah di Indonesia. Jakarta, Sinar Grafika.

Salam, A. 2015. Kedudukan Fungsi Peraturan Daerah (PERDA) sebagai Bagian Dari Hukum Nasional. Pleno Jure, 4(5), 1-12.

Solly Lubis, M., 2009.Ilmu Pengetahuan Perundang-undangan. Bandung, Mandar Maju.

Sunindhia, Y.W., 1987. Praktek Penyelenggaraan Pemerintahan Daerah di Indonesia. Jakarta, Bina Aksara.

Yuliandri, 2009.Asas-asas Pembentukan Peraturan Perundang-undangan Yang Baik; Gagasan Pembentukan Undang-undang Berkelanjutan. Jakarta, Rajawali Press. 